\section{DIGITAL COMMONS \\ @ UNIVERSITY OF SOUTH FLORIDA}

\section{ABO: Interactive Journal for Women in the Arts, 1640-1830}

Volume 3

Issue 2 Volume 3.2 (Fall 2013)

Article 4

2013

\title{
Frances Burney's Cecilia: A Publishing History, by Catherine M. Parisian
}

Lee Kahan

Indiana University South Bend, Ikahan@iusb.edu

Follow this and additional works at: https://digitalcommons.usf.edu/abo

Part of the Dramatic Literature, Criticism and Theory Commons, Educational Methods Commons, Feminist, Gender, and Sexuality Studies Commons, and the Literature in English, British Isles Commons

\section{Recommended Citation}

Kahan, Lee (2013) "Frances Burney's Cecilia: A Publishing History, by Catherine M. Parisian," ABO: Interactive Journal for Women in the Arts, 1640-1830: Vol.3: Iss.2, Article 4.

http://dx.doi.org/10.5038/2157-7129.3.2.4

Available at: https://digitalcommons.usf.edu/abo/vol3/iss2/4

This Reviews is brought to you for free and open access by Digital Commons @ University of South Florida. It has been accepted for inclusion in ABO: Interactive Journal for Women in the Arts, 1640-1830 by an authorized administrator of Digital Commons @ University of South Florida. For more information, please contact digitalcommons@usf.edu. 


\section{Frances Burney's Cecilia: A Publishing History, by Catherine M. Parisian}

\section{Keywords}

Frances Burney, Cecilia, Publishing, Printing, Reading, Book History, Translation, Abridgement, Novel Illustration

Creative Commons License

(c) (i) $\odot$

This work is licensed under a Creative Commons Attribution-No Derivative Works 3.0 License. 
Catherine M. Parisian, Frances Burney's Cecilia: A Publishing History. Burlington, VT: Ashgate, 2012. xxi + 363 pp. \$119.95. ISBN 978-1-4094-1820-7.

Reviewed by Lee Kahan

Indiana University South Bend

In her first journal entry after the publication of Evelina, Frances Burney famously imagines the "power" that "anybody and everybody" has over her work now that it can be read "by every butcher and baker, cobbler and tinker, throughout the three kingdoms, for the small tribute of three pence" (D'Arblay 7). Her second novel, Cecilia, arguably dramatizes this concern, as her heroine attempts to maintain her character against the perpetual misreadings of her many guardians and male admirers. Parisian's bibliographical study brings Burney's fears to life by showing just how many hands Cecilia has passed through in its more than 200 year history and how various literary guardians, from printers to publishers to critics, refashioned the novel's character to accommodate new print forms, editorial strategies, and audience demographics.

Her study begins with a sympathetic account of Burney's own struggles to preserve her artistic vision as she labors to meet hasty deadlines while defending the novel against Samuel Crisp's suggestions for revision. Burney often adopts the pose of the dutiful daughter in her journal and letters, but Parisian reveals moments where she drops that façade to position herself as a confident "innovator in the genre," who rejects Crisp's advice on the grounds that it would make her ending mirror "the last Page of any Novel in Mr. Noble's circulating library" (qtd. in Parisian 9). By associating the circulating library with the superficial tastes of mass culture, Burney implies that Crisp, like many of her male characters, is a bad reader, whose tastes are governed by the fashions of the marketplace. Of course, this opposition between writing and the market obscures the degree to which Burney sought to capitalize on the fame of Evelina - a motive that becomes clear when she complains about printing delays and being "jockeyed" out of payment by her publishers, Payne and Cadell. Through a sensitive account of the complex and laborious task of printing and of the financial strain that it placed on its publishers, Parisian suggests that Burney's complaints were largely unwarranted. Indeed, she shows that, in comparison with the practices of other publishers of the time, the remuneration Burney received was not only fair but generous.

The following two chapters trace the "afterlife" of the novel as publishers and editors both at home and abroad reshaped the novel to reach new audiences. Nineteenth-century British editors adapted Cecilia to print vehicles like the novel series and the book-in-parts edition, both of which made the novel cheaper and therefore more attractive to a working class audience. However, because the novel was so long, it was usually abridged, with chapters sometimes added to summarize excised portions of the novel. Parisian also attends to how novel series in particular reframed the meaning of the work through introductions that emphasized "the theme of national identity," even as those series included some translations of foreign novels (34). Burney's novels were to play a different role in British national identity later in the century when they were repackaged as historical artifacts catering to the new emphasis on English classics in the educational curriculum. While early nineteenth-century publishers presented Burney's novels as exemplars of the genre, they were now being framed as inferior writings that were nonetheless 
essential for cultural literacy. This reclassification as "classics" marketed to "the Upper-MiddleClass of General Reader" changed the editorial process itself, which began to reflect principles of faithfulness and objectivity in keeping with the novel's new stature as historical artifact (Ellis qtd. in Parisian 45).

Parisian thus gives a rich sense of the numerous Cecilias available to the British reading public over the course of the nineteenth century. This diversity was compounded abroad due to the complexities of translation and the bilingualism of reading audiences. Parisian provides an interesting discussion of the "competing theories and practices of translation" in France (81), where the older method of altering the text to fit its new national context competed with a new approach rooted in scientific principles of "exactness and accuracy" (83). Readers had even more choices in countries like Germany, where the bilingualism of readers led to the simultaneous circulation of English, German and French editions. Hence, while Cecilia was a commercial success abroad, Parisian suggests that its audience was reading very different versions of the novel.

While Parisian's study offers numerous brief insights about how the novel's packaging and editorial framework shaped the reading experience, literary critics like myself will undoubtedly wish that she had spent more time developing them, instead of focusing so much on numerical data. For example, she provides an exhaustive account of the number, cost and size of nineteenth-century abridged editions, but we learn little about the role of the excisions themselves, which critics like Leah Price have shown reflected and shaped changing assumptions about the value of novel reading. How the various editions of Cecilia encouraged particular readings of the novel perhaps comes through most clearly in the final chapter on the novel's illustrations, in which Parisian finds a shift in emphasis from sensibility to plot and character. Parisian also sheds light on how these images reveal assumptions about the relationship between author and work, as several of the portraits of Cecilia bear a remarkable resemblance to Burney herself. However, the earlier chapters are more interested in the publishing and printing minutiae of the novel's various editions than in the ideological or epistemological implications of editorial choices. While a testament to Parisian's meticulous research, the lists of figures and dates sometimes become overwhelming and obscure the story that she is trying to tell. This is particularly the case in the first chapter, where her otherwise interesting account of the publishing process is interrupted by a detailed list of press figures and an exhaustive calculation of the number of sheets of paper necessary for the first print run. She often provides such information in table format as well, which seems to render unnecessary the repetition of this data in the account itself.

Of course, such criticism is perhaps unfair since Parisian's study is not a work of literary criticism but of bibliography. For the most part, the book delivers on her promise to "tell a story that incorporates not only the physical features of [Cecilia] but also the accounts of its composition, printing, publishing, reading, and circulation" (1). Of these five areas, "reading" certainly receives the least attention. While she occasionally provides the opinions of Cecilia's reviewers, Parisian tends to focus on their superficial likes and dislikes, without delving into what those preferences suggest about reading practices or values. I was even more curious about why people stopped reading Cecilia for much of the nineteenth century, after it had received pride of place in many novel series only decades before. While Parisian attributes the novel's 
waning popularity to the increased number of works available to the public, one wonders if it also had something to do with how they responded to the content of the novel itself: perhaps Victorian culture was less comfortable than its predecessors with a woman writer who provides frank accounts of suicide, equates patriarchy with insanity, and refuses to allow readers to indulge in a fantasy of domestic bliss.

To ask such questions, one must consider the readers' interpretations of Cecilia as an integral part of its history, which also necessitates some attention to the content of the book itself. While critics like Janine Barchas have demonstrated the rich interpretive possibilities that we sacrifice by ignoring a literary work's material form, we must likewise be careful of moving too far in the other direction and reducing the book to pure materiality - an object so many inches tall and including so many sheets of paper. In The Practice of Everyday Life, Michel de Certeau suggests that "to read is to wander through an imposed system . . . analogous to the constructed order of a city" (169): authors, printers and publishers are its architects, tables of contents and chapter headings are its signage, sentences are its roads. Parisian provides a rich account of how this city is incessantly under construction: new roads are built and old ones closed, signs point readers in new directions. However, she does not account for the novel that readers themselves invent as they navigate its pages or the cultural forces at work in their daily lives that might inform such inventions. This, too, is the history of the book. While Parisian has given us the blueprints for how Cecilia was built, it remains for future critics to populate it.

\section{Works Cited}

D'Arblay, Frances Burney. Diary and Letters of Madame D'Arblay. Ed. Charlotte Frances Barrett. Vol. 1. London: Colburn, 1842. Print.

De Certeau, Michel. The Practice of Everyday Life. Trans. Steven Rendall. Berkeley: U of California P, 1984. Print. 